\title{
متطلبات تطوير مؤسسات رياض الأطفال بمصر في ضوي \\ الفلسفات التربوية المعاصرة
}

\section{نعيمل مجاهر الشبكى مجاهر عبر الله}

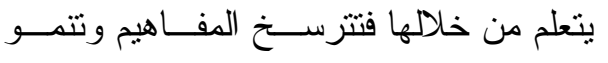

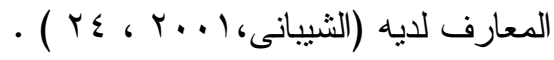

لقد احتلت الدر اسات التى نتاولت طفل ما قبل المدرسة ومرحلة ريــاض الأطفــال مكانة مميزه لدي المفكرين و التزبويين بهدف تطوير مرحلة رياض الأطفال و إعداد الطفل

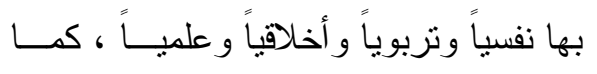

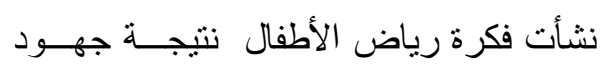

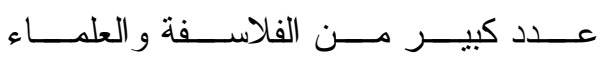

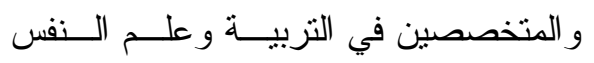

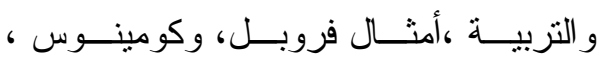
وروسو، وبستا لوزي ،ومنتسوري و وآخرين

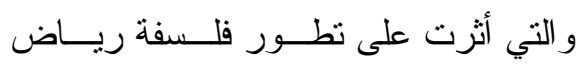

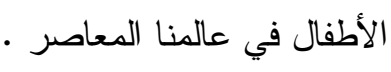
لذا أجمع الباحثون في المجال التربوي

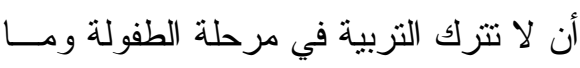

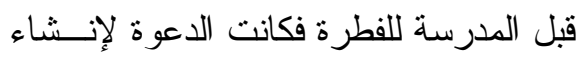

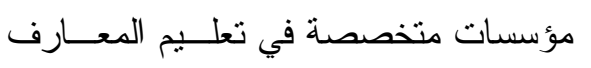

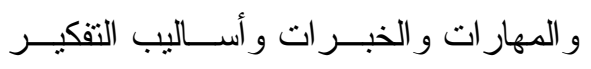

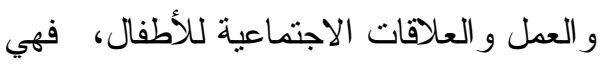

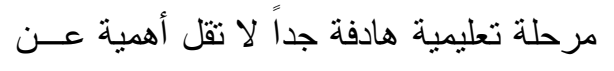

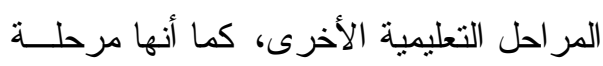

إن مرحلة رياض الأطفال مــن أهــم فئد

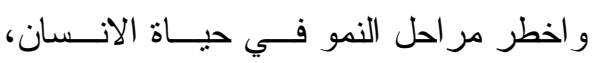

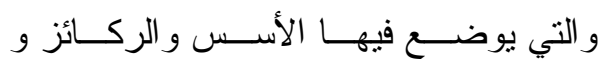
المبادئ التي تقام عليها شخصيتة في جو انبها

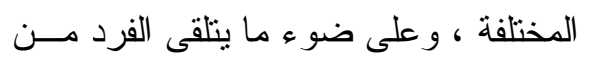

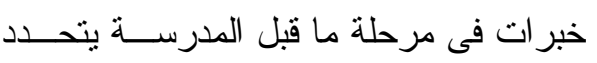

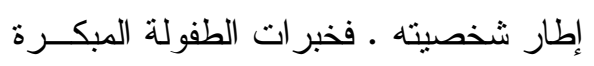
تحفز جذور عميقة فى شخصية الطفل وتحدد

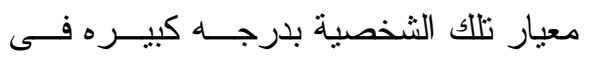

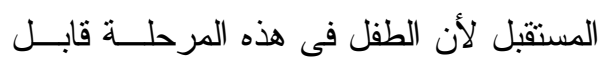

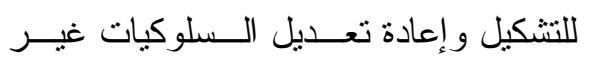
المرغوبة إلى سلوكيات مرغوبة ـ (شريف، . (10، r.) وفي العصر الحديث ت نز ايدت أهميــة

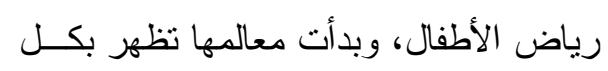

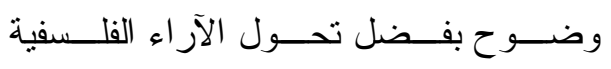

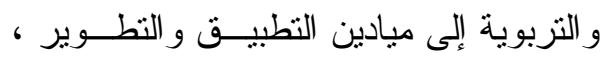
حيث اعتبرت هذه الفلسفات أن طفل الروضة ونة ولنة

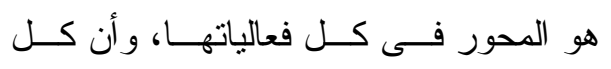
عناصر النظام التزبوي فيها تعود الطفل على في لئل

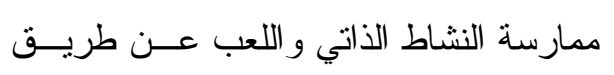
الاستكثاف الحر ليتوصل بنفسه إلى مو اقف 
مؤسسات رياض الأطفال ( شرف الــدين ،

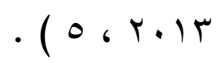

ولقد اختارت الباحثة الفلسفة التربوية

لمنتسوري كمدخل لتطوير ها لأنها جمعــــ معظم الفلسفات التربوية وز ادت عليها مــن

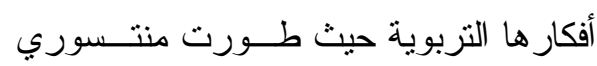
فلسفة تربوية حديثه بناء علــى ملاحظاتهــا

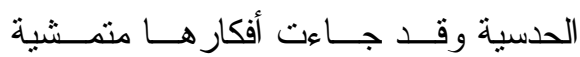
ومنسجمة مع الأفكار التى نادى بها روســو

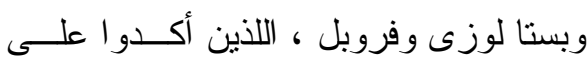
الطاقات الكامنة لاى الطفل وقدرتــهـ علـى لـى التطور فى ظروف بيئيــة تتـسم بالحـبـ

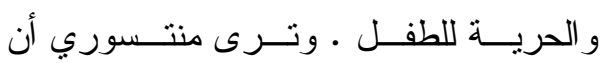
الطفولة ليست فقط مرحلة يجب العبور منها إلى مرحلة الرشد ، ولكنها الــركن الآخــر

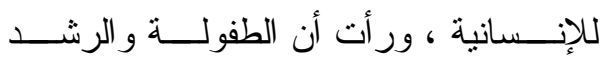

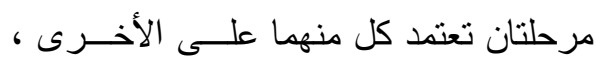

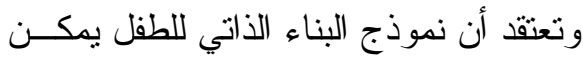

الكثف عنة فقط من خلال عملية النطور.

كما تتفرد فلسفة منتسوري في تربيـــة

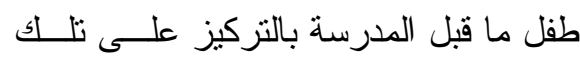

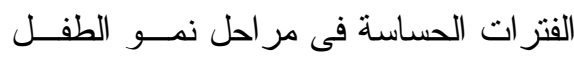
(الجسماني و العقلي و المعرفي و الحسى ) وقد كان الجديد لديها فى إنها جمعت بين الفلسفة ولهي

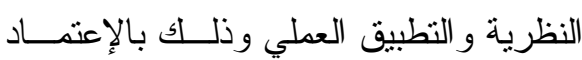

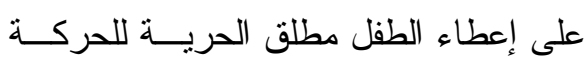
و العمل فى نطاق بيئة مبنية ومخططة بعناية
تربوية متميزة وقائمة بــــاتها لهـــا فلـــفتها التزبوية و أهدافها الــسلوكية وســـيكولوجيتها التعليمية و التعلمية الخاصة بها ـ التهائ

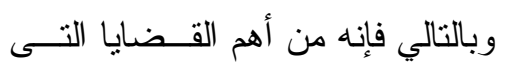
يجب الاهتمام بها و التصدي لها قضية وجود فلسفة تربوية واضحة ومعلنة لمرحلة ما قبل

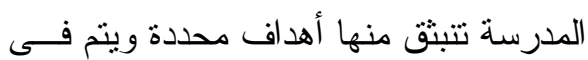

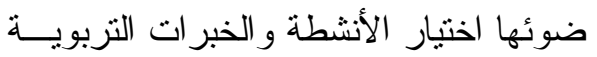
المناسبة لطفل هذه المرحلة ويتم تقــويم مــــا

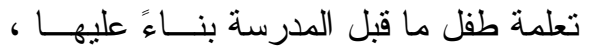
وتتمية وعى الأطفال بالحاضــر و المـستقبل يتطلب وضع فلسفة تربوية تعمل على تغيير

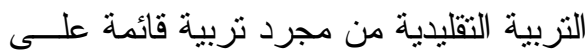
نقل المعلومات و المعارف التى يملكها الكبار

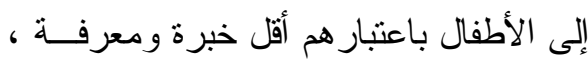
و الاعتماد على أساليب تدريسية تجعل مــنهم مقلدين أو متلقين سلبيين ، إلى تربية جديــدة

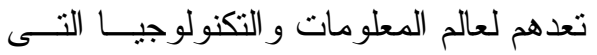
تحتاج لأفر اد متميزين ومبدعين ، مسستعدين

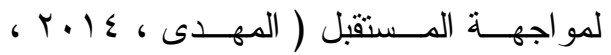
( $10 \mathrm{~V}$ وتتطلب التربية الحديثة فـي ريــاض الأطفال تطبيق النظريات العلمية و الفلـسفية

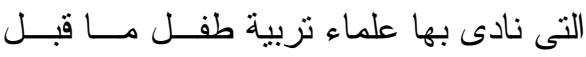

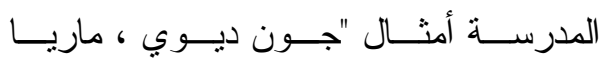

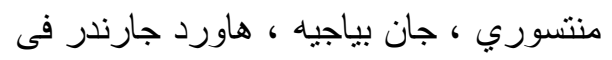


و واستخدام الفلسفات التربوية المعاصرة فــي مجال رياض الأطفال ، ويشير الو اقع إلى أن

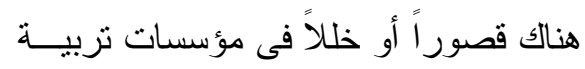
الطفل فى مرحلة ما قبل المدرسة كما أكدته

نتائج بعض الدر اسات السابقة منل :-

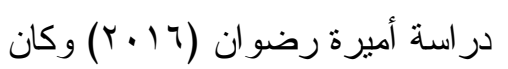
من أهم نتائجها: وجود العديد من المشكلات

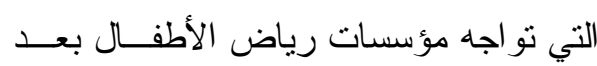
الاعتماد مما يهددها بسحب الاعتماد، ووجود لتوني عجز كبير في عدد المعلمـات و العـاملات برياض الأطفال.

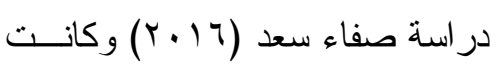
من أهم نتائجها: قلة الاهتمــام بمؤسـسـات رياض الأطفال في مصر بتطوير المنــاهج

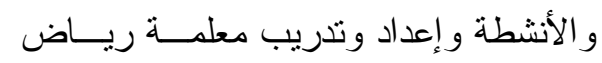

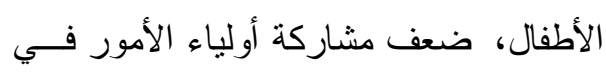

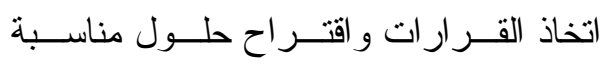
للمشكلات التي تتعرض لها المؤسسة ، الـي

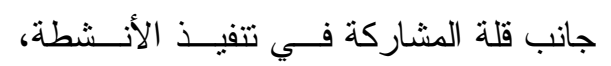
انخفاض الإمكانيات المادية داخل الروضـــة، و عدم تو افر أجززة كمبيونز داخل القاعات.

مشكلة الدراسة: تعد فلسفة إعداد الطفل فـى مــصر

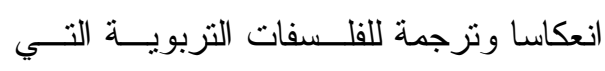
تتبناها، وبما أن مرحلة رياض الاطفال لهـــا

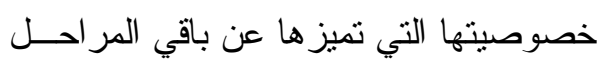

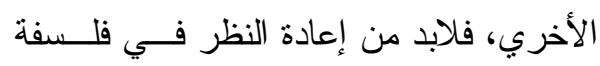

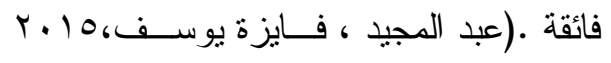
. (o^, ويعتبر وجود سياسة تزبوية لطفل ما

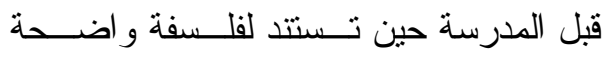

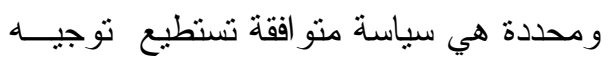
مجمل العمل التزبوي الموجه للطفل تخطيطاً

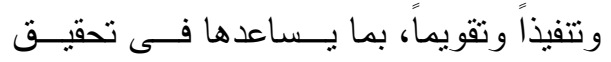

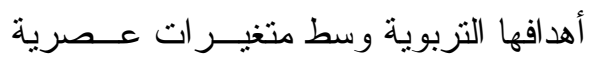
فرضت أهدافاً و أعباءً جديدة على مؤسـسـات تربية الطفولة التى تسهم فى تكييف الأجيـال

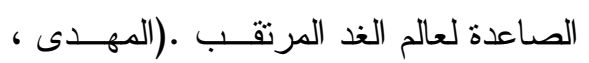
- (17)، r.)

وبالتالي فان الاهتمام بمرحلة الطفولة

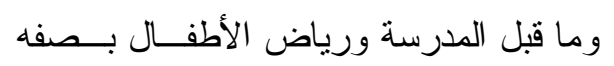
خاصة يعد استثمارًا أمنل لبناء مـستقبل أي الطي

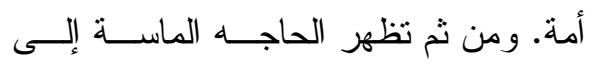
ضرورة تطوير مؤسسات رياض الأطفــال فى ضوء بعض الفلسفات التربوية المعاصرة وكيفية توظيف فكر بعض الفلاسفة وتطبيـت فئن

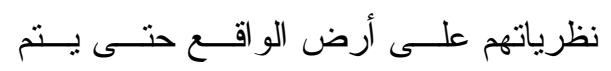
الاستفادة من هذا الفكر الفلسفي الر ائد فى هذا

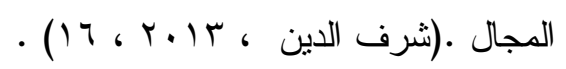
ومن خلال عمل الباحثة فــى مجــال

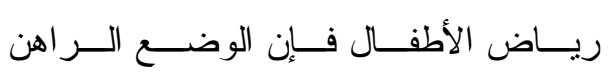

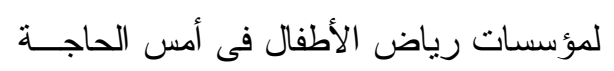
إلى تطوير ها حتى يتسنى لها تحقيق وظائفها

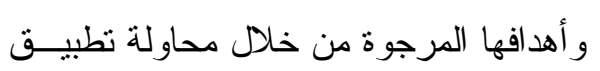




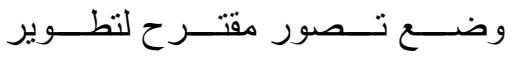

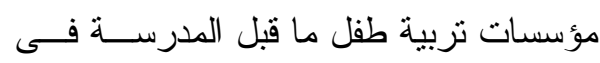

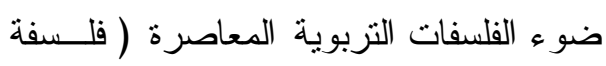
منتسوري التربوية) كمثال للتطويروذلك من

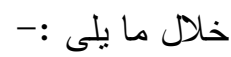

• التعرف على الفلسفة التزبوية لمنتسوري

• تحديد أهم المشكلات التي تعوق تطوير

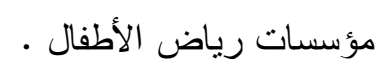

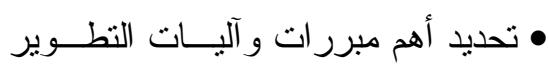
لمؤسسات تربية طفل ما قبل المدرســـة في ضوء الفلسفة التربوية لمنتسوري.

أهمية الدراسة:

تتضح أهمية الدراسة الحالية فيما يلى :1- إثراء المكتبة البحثية في مجال تطوير

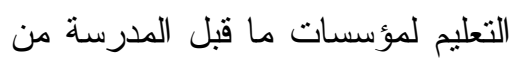
خلال تحديد أهم منطلبات التطوير في ملي في

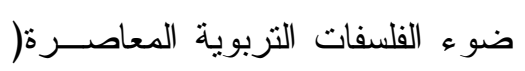
فلسفة منتسوري كنموذج للنطبيق)

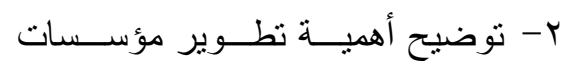

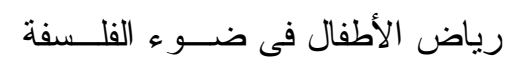

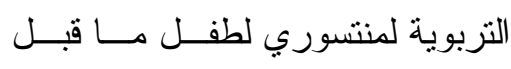
المدرسة مما يساعد المعلمات وبيئــة التعلم فى مسايرة وتطبيق النظريــات الفلسفية و التربوية الحديثة . r- مساعدة بيئة التعلم فـى مؤســسات

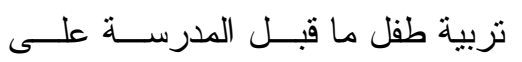

إعداد الطفل بها و أهدافها و أساليب تحقيقهــا في ضوء التقدم و التغير ات المعاصرة ومع وجود الحاجة الملحـــة لتطــــير و إصلاح مؤسسات ما قبل المدرسة؛ تتــضه ضرورة الاهتمام بفلسفة منتسوري التربوية ؛ كأحد رو اد الفكر التربوي حيث حققت نجاحا كبير ا على مستوى العالم ، خاصة أنها تهـتـ

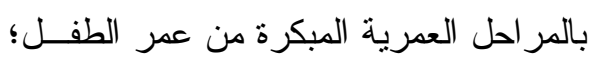

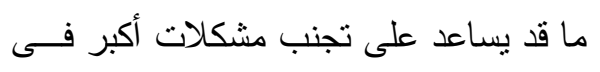
المر احل العمرية التالية. بناء على ما سبق فــإن مـشكلة الدراســة الحالية تتبلور فى العؤال الرئيس التــالي ملئي - كيف يمكن نطوير مؤسـسـات ريــاض

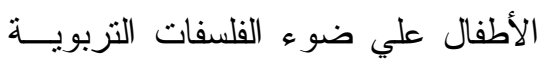
المعاصرة ؟

\section{ويتفرع من هذا السؤال الأسئلة التالية:} 1- ما الاطار المفاهيمي لرياض الأطفال

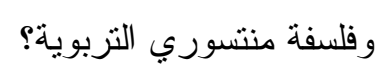

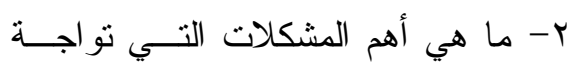

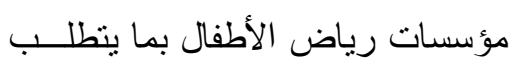

$$
\text { تطوير ها؟ مؤسبن }
$$

r- ما التصور المقترح لتطوير مؤسسات

رياض الأطفال علي ضـــوء الفلـسفة مؤسئة التربوية لمنتسوري؟

أهداف الدراسة: 
مصطحات الار اسة:

المتطلبات (Requirements) : (المعل

المتطلبات هي الاحتياجات الو اقعيـــة

و التطلعات المستقبلية التى تسير وفق سياسة تعليمية ، تسعى إلى تحقيق الأهداف التعليمية

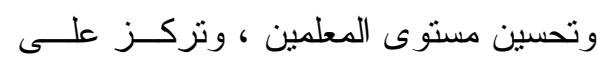

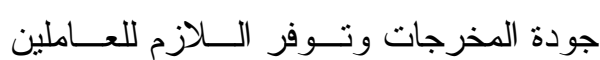

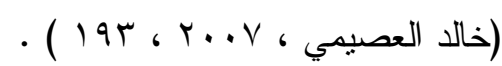

يقصد بمتطلبات تطوير مرحلة رياض الأطفال " جميع الإمكانات المادية و البـشرية لـشية المطلوبة لتحقيق الأهداف المنشودة من هــــه المرحلة " -: Development" التطوير يعرفه جابر طلبه:- هـــو مجموعــة

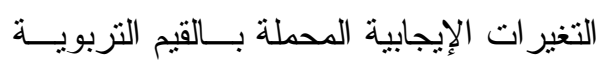
و العلمية التى يمكن حدوثها فى نظام رياض الاض بهن الأطفال بقصد زيادة فعاليته وتحقيق كفايتــه

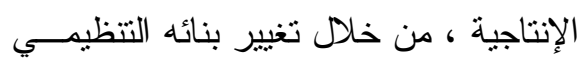

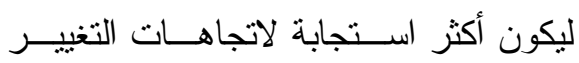

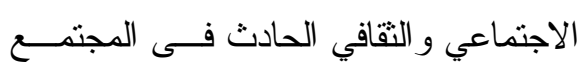
المصري ، و أكثر مو اكبة لمعطيــات التقــدم

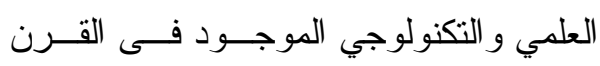
الحادي و العشرين (طلبة ، 1999 ، 199 ه ). - و هناك تعريف آخر للتطوير "النطــــير

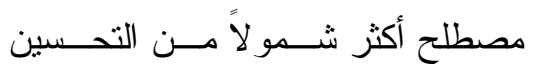
و التعديل، فهو يثير إلى إدخال تجديدات لتئل
مسايرة النظور و التغير وتحسين أداء المعلمة وتفعيل دور ها داخل القاعــة

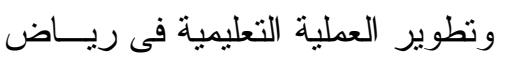

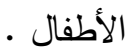

ع- الارتقاء بمستوى معلمــات ريـــاض

الأطفال أثناء الخدمــة حتــى تـسـاير النطور العلمي العالمي و المتطلبــات

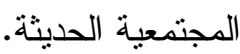

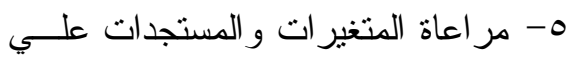

الساحة التربوية و الخاصة بمؤسسات

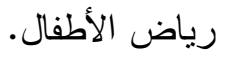

يستقيد من هذه الدر اسة جهات عديدة

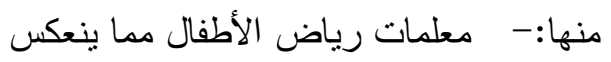
أثرة على طفل ما قبل المدرسة، القـائمون على سياسة تربية الطفل فى جمهورية مصر

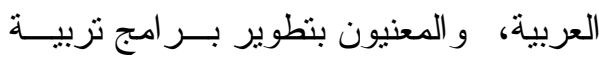

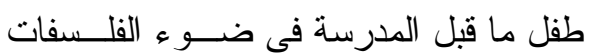
التزبوية المعاصرة . منهج الدراسة : استخدمت الدر اسة الحاليــة المــنهج الوصفي باعتباره هو المنهج الملائم لتحقيق

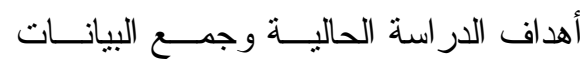
و المعلومات اللازمة لتحديد واقع مؤسسات

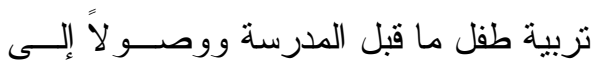

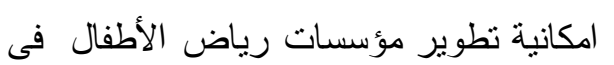

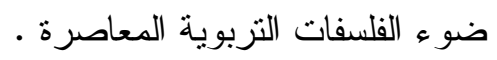


يدرسون للحصول على الــدرجات الجيــدة

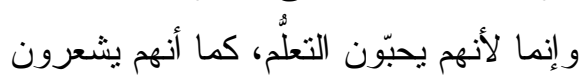
بقدرتهم على التأثنير في مجتمعـاتهم وفـي لئي

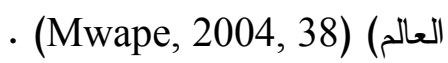

\section{وتعرف فلسفة منتسوري التريويـــة}

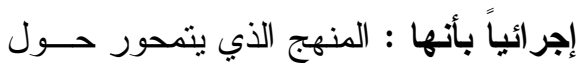

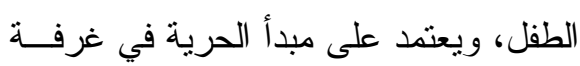

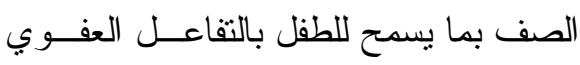

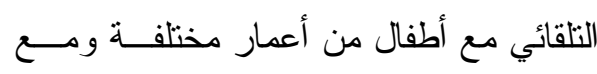
الأدو ات في بيئة معدّة نتتاسب مـــع الــتعلم

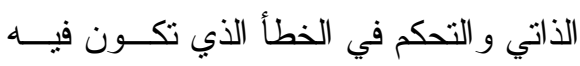
المعلمة مرشدة ومشرفة على الأنشطة التـي اختار ها الطفل ذاتياً.

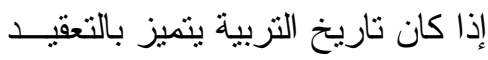

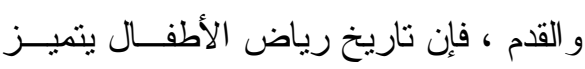

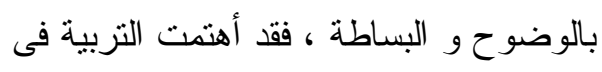

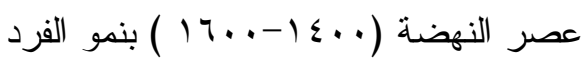
و الاهتمام به، وز اد الاهتمام به ككيان سياسي الهي

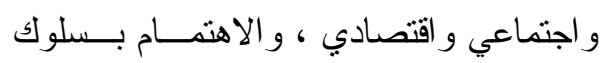
الفرد وتكوين التفكير فى جميع شئون الحياه

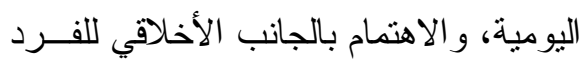

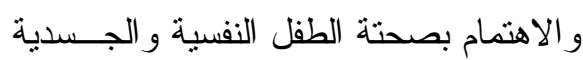

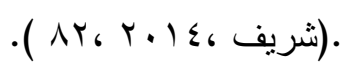

ماهية ريــاض الأطفــال : تعـرف (بـان

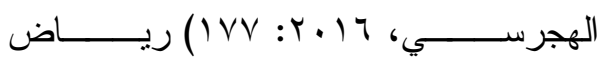
الأطفال Kinder garten بأنهـــا مؤسـسـات تربوية تعليمية حكومية، يلتحق بها الأطفــال
ومستحدثات يقصد بها رفع كفاءة العملية

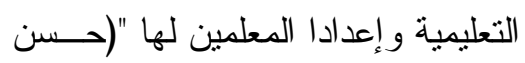

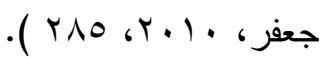

التعريــف الاجرائـــي للباحثــة بــأن

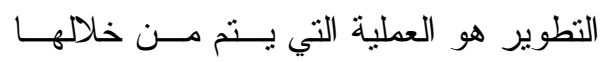

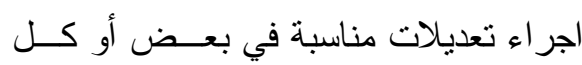
مكونات العملية التعليمية برياض الأطفال في مصر في ضوء بعض الاتجاهات العالميـــة التزبوية المعاصرة ، وذللك من أجل تحسـسين

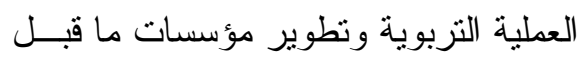

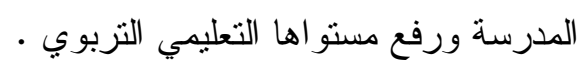
فلسفة منتسوري التربويـــة: " هـــي وني

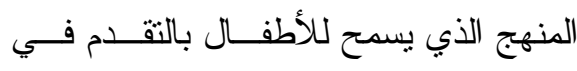

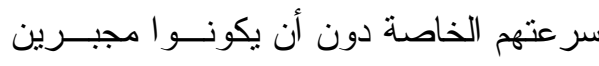
على الالتز ام بالمعايير و القو اعد الاصطناعية ، فالدروس تعرض على الطفل بشكل فردي

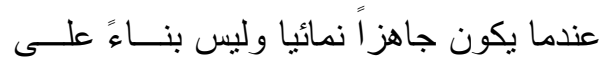
جدول مو اعيد ثابت ، فطريقة منتسوري في

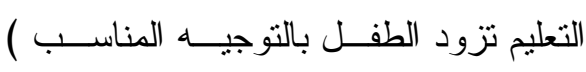
الدافئ ( في بيئة معدة جمالياً ومحفّزة لتقابل

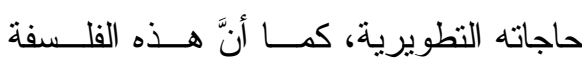

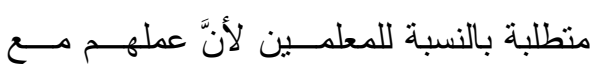

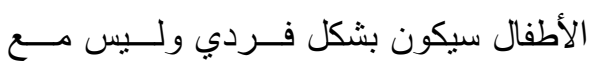
الصف بكامله، فكل تقدم يحققه الطفل مر اقب

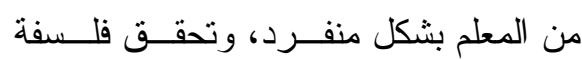

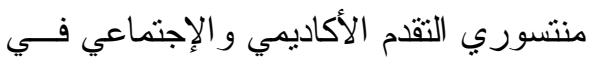

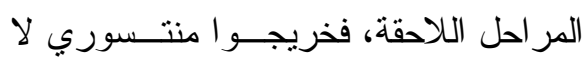




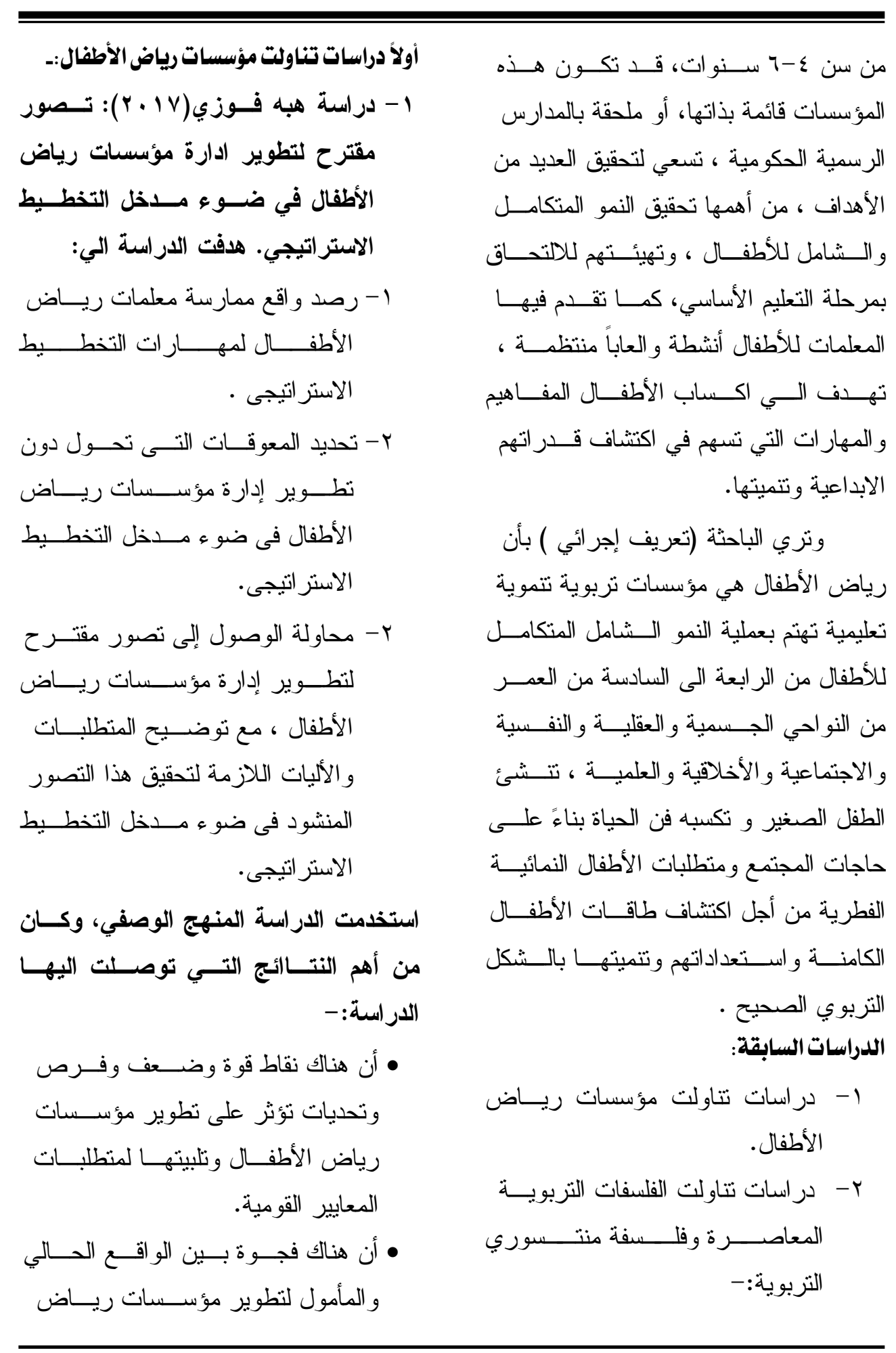




$$
\begin{aligned}
& \text { رياض الأطفــال بمــصر فــي ضــوء } \\
& \text { المعايير القومية. } \\
& \text { هدفت الدراسة الي: }
\end{aligned}
$$

يتمنل الهدف الرئيس للبحث في وضع

خطة استراتيجية مقترحة لتطوير مؤسسات رياض الأطفال في ضوء المعايير القومية وفي سبيل ذلك يسعى البحث إلى تحقيق الأهداف الفرعية التالية:

1 - نشخيص و اقع مؤسسات رياض الأطفال

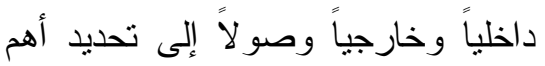

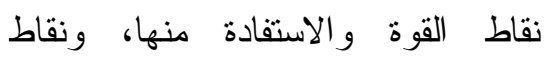
الضعف التي تعوق مؤسسات الرياض

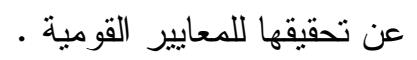

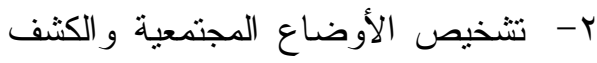

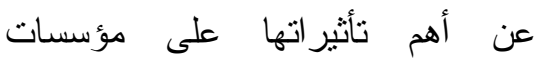
الرياض لاكتشاف الفرص ومواجهة

$$
\text { التحديات في ضوء المعايير القومية. }
$$

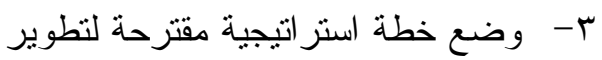

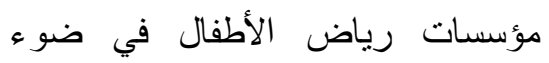

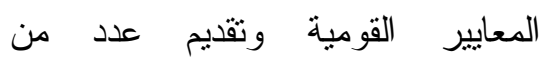
الاستراتيجيات البديلة و والمقارنة بينها

$$
\text { لاختيار الأفضل. }
$$

استخدمت الدراسة المنهج الوصفي وتوصلت الار اسة الي:-

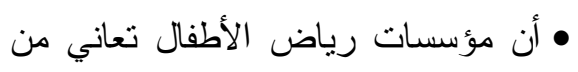
نقاط الضعف الكثيرة ، ووجود القليـلـ نـل من نقاط القوة.

$$
\begin{aligned}
& \text { الأطفال، و لابـــــــنـ وضـــع بــــائل }
\end{aligned}
$$

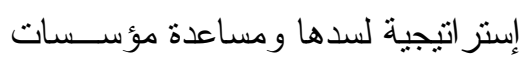

$$
\begin{aligned}
& \text { رياض الأطفال على تحقيــق المعـايير }
\end{aligned}
$$$$
\text { القومية. }
$$

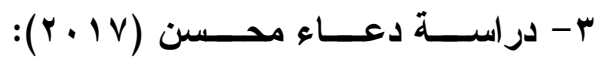

متطلبات تطوير مؤسسات تربية الطقل في مصر علي ضوء المدارس صديقة الطقل: - وهدفت الدراسة الي:-

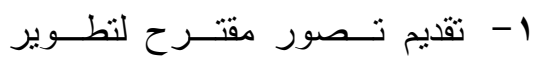
مؤسسات نربية الطفل في مــصر لـرح علــي ضـــوء ســـمات المـــدارس فئس فئس

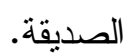
r- التعرف علي و اقع مؤسسات رياض الأطفال ومتطلبات تطوير ها.

واســتخدمت الاراســة المــنهج الوصــفي لملائمتة لطبيعة الدراسة. وكاتت أهم نتــائج الدراســة :- أن المدرسة الصديقة للطفل هي المدرسة التـي تقدم خدمات تعليمية وتربوية ممتازة فــي ان هدئ

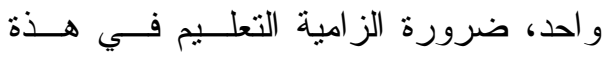

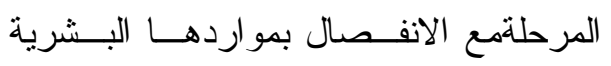
و المادية عن المدارس الابتدائية وضــرورة توفير معلمات متخصصات مهنياً و أكاديميــاً وضئ

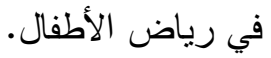

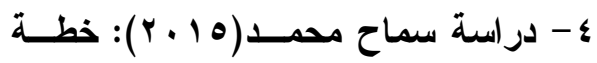
إستر اتيجية مقترحة لتطوير مؤسسات 
ثانيــ_دراسـات تناولـت الفلـسفات التزبويــة المعاصرة وفلسفة منتسوري التربوية:ـ

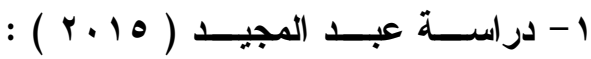
بعنوان " دراسة مقارنة بـين مــنهج

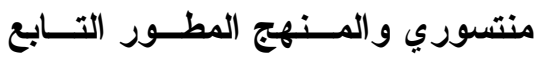

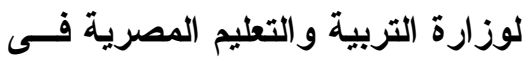

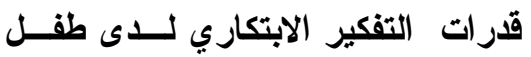

$$
\text { الروضة " }
$$

هدفت هذه الار اسة الى المقارنة بـين

منهج منتسوري بــالمنهج المسـتخدم فـى الروضـات التابعة لوز ارة التزبيـــة و التعلــيـم

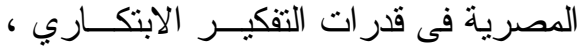
اعتمادا على منهج المقارنة بين مجمــو عتين من الأطفال احداهما من روضات منتسوري و الأخرى لأطفال من روضة تابعة لـــوزارة التربية و التعليم المصرية التهن

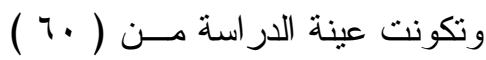
طفلاً على مجمو عتين ، وكانت أداة الدر اسة اختبار رسم الرجل لقياس درجة الذكاء لجود

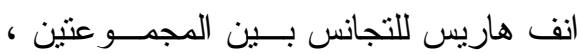

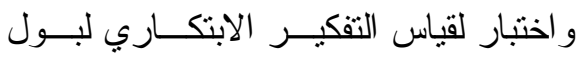

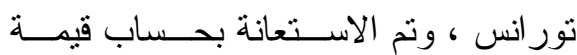
T.Test المتوسطات بين المجمو عتين. وكانت من أهم نتائج الدراسة وجــود

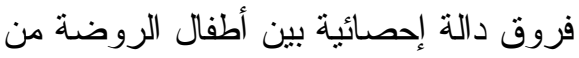

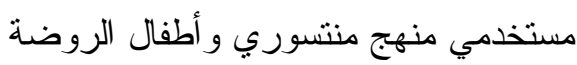

• تواجة مؤسسات رياض الأطفال تحديات

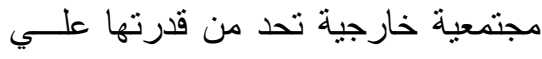
القيام بدور ها في ضوء مؤشرات القيمة

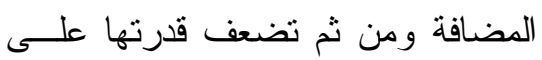
أداء وظيفتها كمؤسسة تعليمية.

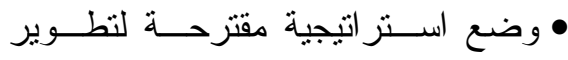

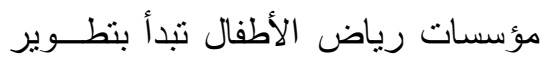
أهد افها و البر امج و الأنشطة .....الخ.

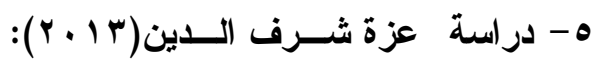
إعداد معلمات رياض الأطفال في ضوء

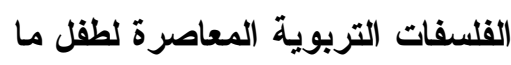
قبل المدرسة : هدفت الدراسة الي:- التعرف على فلسفات وأهداف تربية طفل ما قبل المدرسة، دليل واقع إعداد معلمات رياض الأطفال في جمهورية مصر العربية وتوظيف فلسفات تربية طفل ما قبل المدرسة في إعداد معلمات رياض الأطفال، تحديد أهم منطلبات تطبيق فلسفات طفل ما قبل المدرسة في إعداد معلمات رياض الأطفال، تقتصر الدراسة الحالية علي تحليل محتوى برنامج الإعداد لكلية رياض الأطفال جامعة القاهرة، تستخدم الدراسة الحالية مقياس من تصميم الباحثة لتحليل محتوي برنامج إعداد معلمات رياض الأطفال في لبن ضوئه. 


$$
\begin{aligned}
& \text { بعض مهارات الحياة العملية لاي طقل } \\
& \text { الروضة من وجهة نظر الأمهات. } \\
& \text { هدفت الدر اسة إلي التعرف على مدى }
\end{aligned}
$$

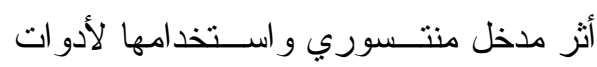

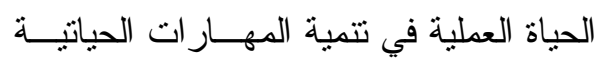

$$
\begin{aligned}
& \text { العملية لدى الأطفال في الروضـات المطبقـــة }
\end{aligned}
$$

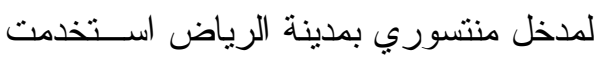

$$
\begin{aligned}
& \text { الار اسة المنهج الوصفي ، و أثنارت نتــائج } \\
& \text { البحث إلى أنز مدخل منتسوري فــي تتميـــة } \\
& \text { مهار ات الحياة العملية لدى طفل الروضــــة. } \\
& \text { و أهمية استخدام مدخل منتسوري في تتميــة } \\
& \text { المهار ات الحياتية لدى الطفل. و أثنتت النتائج } \\
& \text { ممارسة الطفل لمهـــار ات الحيــاة العمليـــة } \\
& \text { الأساسية اليومية، مهار ات العناية الثخصية، }
\end{aligned}
$$

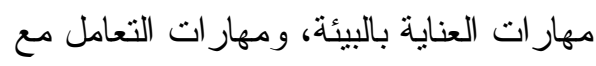

$$
\begin{aligned}
& \text { الآخرين. }
\end{aligned}
$$

M.C. ع دراسة مس ديور هام. روبـن

\section{.(Durham, Robin (2011}

و التي هدفت إلى تحديد ما إذا كان هناك اختلاف بين التقدم الأكاديمي للأطفال فى مدارس منتسوري بتكساس وبين أقر انهم لهاري

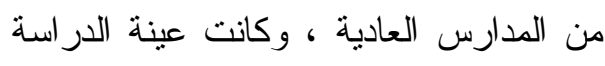

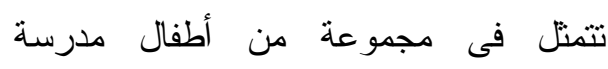

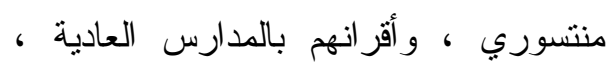
وتضمنت أدو ات الدر اسة : طريقة منتسوري

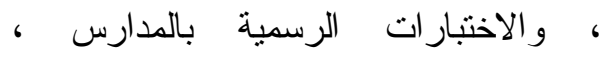
وتوصيات المدرسين ، وكثفت نتائج الدر اسة
التى تستخدم المنهج المطور التابع لــوزارة

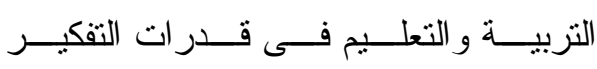
الابتكاري

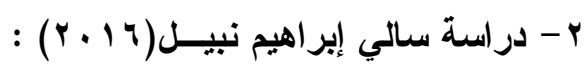
"برنامج لتنمية بعض المهارات الحياتية

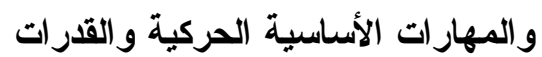

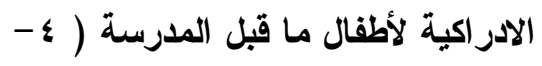

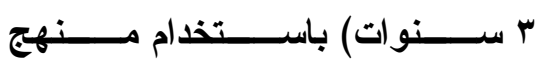
المنتسوري. هدفت الدراسة الي:- التعرف علـي

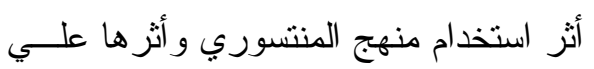
تتمية بعض مهار ات الأطفال مثل المهــار ات

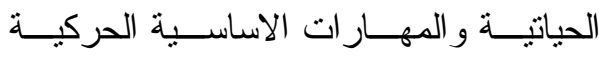
و المهار ات الادر اكية.

و استخدمت الباحثة المنهج التجريبي، باستخدام تصميم المــنهج القبلــي و البعـدي لـنـي لمجمو عتين. توصلت الار اسة الي:- أن برنــامج

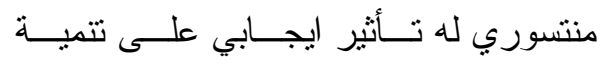

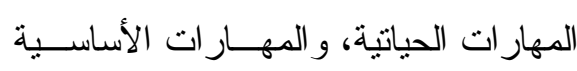
الحركية و القدر ات الادر اكية الخاصة بأطفال ما قبل المدرسة، حيث أنه نوجد فروق ذات دالة احصائية لصالح المجمو عة التجرييية في كل المتغير ات قيد البحث.

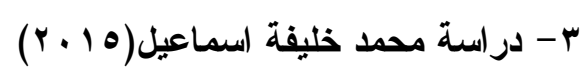

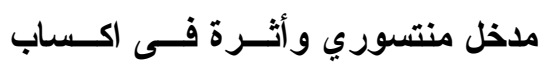


المبكرة الممارسات فى الفصول الدراسية ،وذللك من خلال المقارنة بين استخدام نهجين مختلفين فى بيئة التعلم الأول على أساس أن

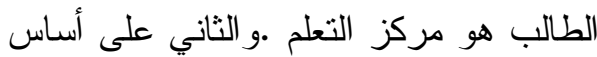
أن البيئة التعليمية أساس التعلم هنم جمع لنع البيانات فى هذه الدر اسة النوعية من الطلاب فى أسلوبين مختلفين من أساليب الدورات وكان المحتوى لكل دورة تدرييية متمانلين. ،ومع ذللك يدرس مدرب واحد فى بيئة تعليمية على أساس أن الطالب هو المركز بينما المدرب الآخر يدرس على أساس مركز البيئة التعليمية .

نتائج الدراسة :- اظهرت البيانات أن الطلاب الذين ينم وضعهم فى مركز التعلم يزيد من فرص تطوير الحكم الذاتي و التحفيز الداخلي مقارنة بالطلاب فى البيئة غير المستتدة إلى مركزية الطلاب .

\section{تعقيب عام على الدراسات السابقة.}

اتفقت جميع الدراسات السابقة

على أهمبة مرحلة رياض الأطفال

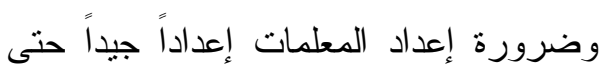
تفي بمنطلبات هذه المرحلة، حيث اوصت جميع هذه الدراسات بأهية الدور الحيوي الذى يقع على عاتق معلمة رياض في الأطفال الحيوي ال ال

قامت هذه الدراسات بالإشارة إلى توضيح محور أو أكثر من الهحاور الهامة
عن أن تلاميذ مدارس منتسوري قد حصلو ا على نسب أعلى فى الاختبار ات الرسمية من من فئن

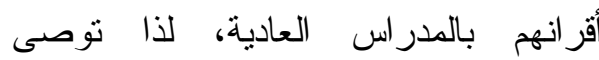

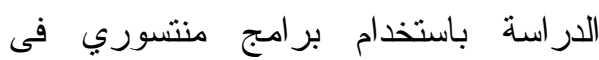

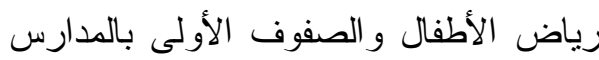

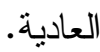

Mallett, دراسة ماليت جان ديفيز - دائه

\section{. (Jan Davis (2013}

و التي هدفت إلى مقارنة التحصيل

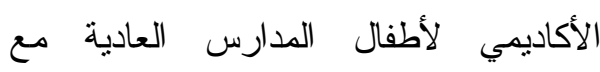
أقرانهم فى مدارس منتسوري ، وتكونت العينة من أطفال المرحلة التمهيدية بمدرسة

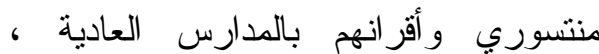

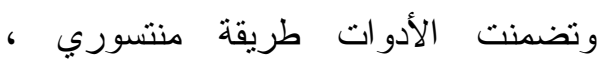
اختبار ات التحصيل العادية بالروضة وكثفت التدي نتائج الدراسة أن أطفال المرحلة التمهيدية الذين ينتمون لمدرسة منتسوري قد حققوا

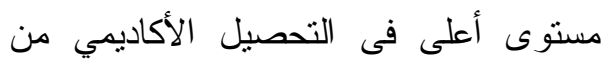
أقر انهم بالروضة العادية.

Amy E.Allenm m :((2008

الاستر اتيجيات التعليمية فى تعليم المدرسين فى مرحلة الطقولة المبكرة (مقارنة بين

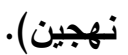
هدفت الدراسة إلى :- التعرف على لى لئ أثز تعليم الطالب المعلم لمرحلة الطفولة 
فى إعداد معلمات رياض الأطفال و إعداد وتطبيقها على أرض الواقع فى رياض

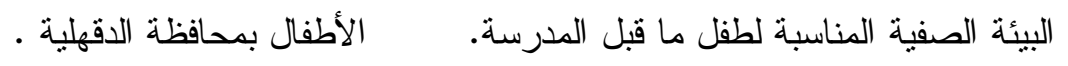
بعض هذة الدراسات كانت تهنم وسوف يستقيد البحث الحالي من

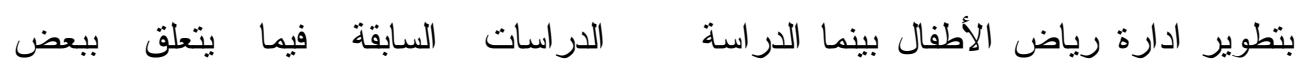

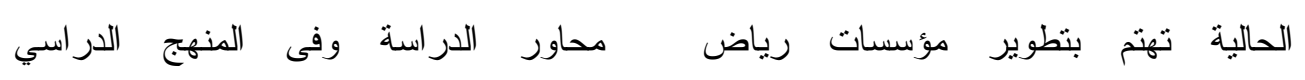

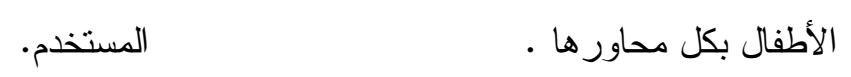
بعض هذة الدراسات اهتم بدراسة الأهمية التربوية لمؤسسات رياض الأطفال

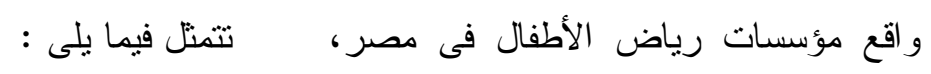

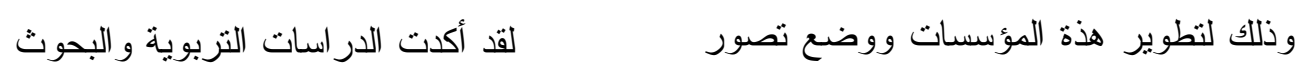

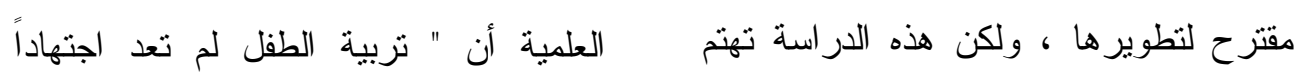

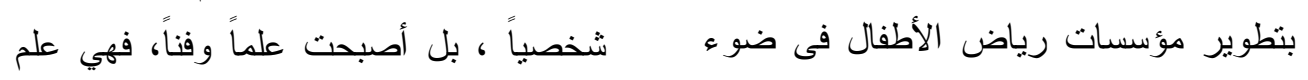

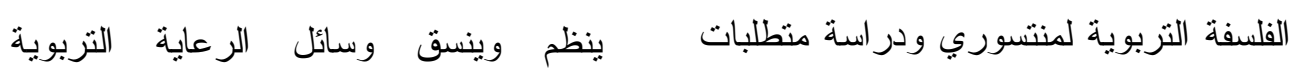

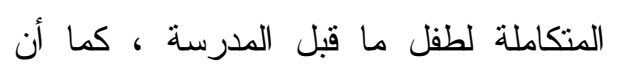
التطوير تربية الطفل ورعايته وتحقيق مطالبه تعتبر

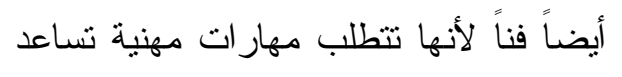
بعض هذة الدراسات اعتمدت علي تطبيق معليير الجودة الثاملة من أجل تطوير لتونير

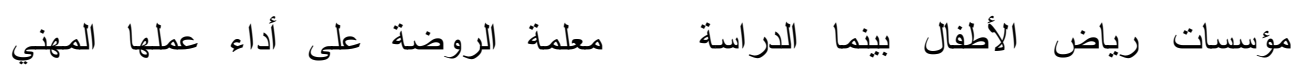
الحالية تعتمد علي تطبيق فلسفة منتسوري و التزبوي بكفاءة وفعالية.

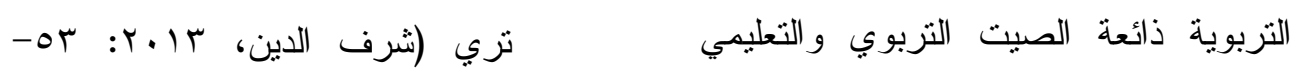

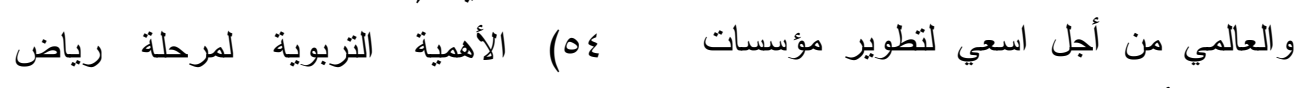
رياض الأطفال فى مصر . الأطفال في النقاط التالية:-

واختلف البحث الحالي عن الدراسات - ت تعليم الأطفال عادات صحية سليمة في

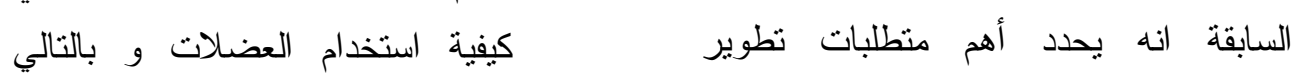
مؤسسات رياض الأطفال فى ضوء الفلسفات

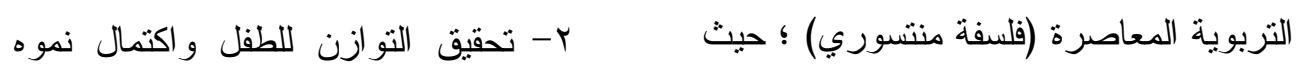
إنها فلسفه تربوية تجمع معظم الفلسفات الالتزام بمعايير الجماعة.

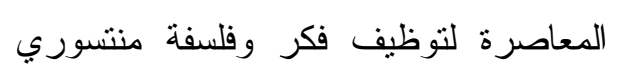


من خلال البيئة الخارجيـــة وحديقـــة

$$
\text { الروضة . منان }
$$

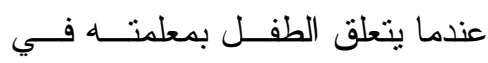
الروضة ، يكون أكثر ارتباطاً وأكثر طاعــة

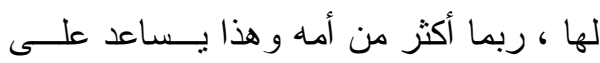
الاستقلاص التدريجي عــن الأم و التـي كــــان يعتمد عليها سابقاً اعتماداً كلياً في كل شئون

$$
\text { حياته . }
$$

اهتم المفكرون و الفلاســفة بمرحلـــة

الطفولة وما قبل المدرسة منذ أمد بعيــــ إلا

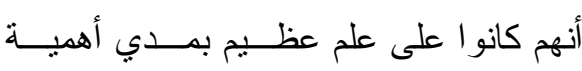
وخطورة هذه المرحلة فــي تـشكيل البنـــاء الانساني ككل ، ووضع التصور المـستقبلي

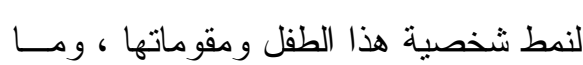
سوف يكون عليه هذا البناء عند بلوغه ، كما

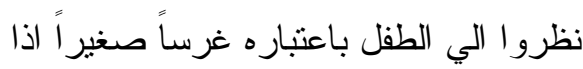

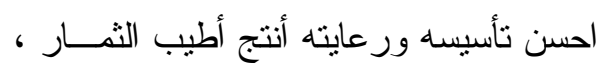

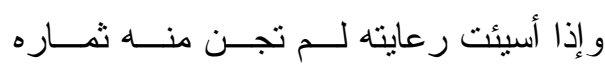

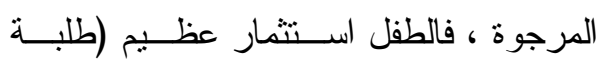
. (r Y T, r... r6

$$
\text { وتعتبر" منتـسوري "مــن زعمـــاء }
$$

الحركة العلمية الحديثة ، و التي قلبت أساليب

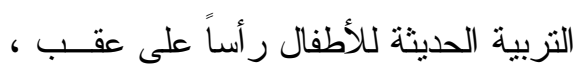
حيث أن الفلسفة التربويــة التــي ابتــدعتها منتسوري تعــد محــصلة در اســات و آراء "روسو بستا لوزي" وفروبل" وكتب التربيـــة

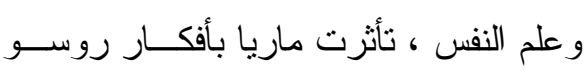

ب- تتمية اتجاهــات الأطفــال الإيجابيـــة للحياة ، وتتمية مهــار اتهم وميــولهم وشخصياتهم و معتقداتهم. ع - تدريب الطفل على التفكير المنطقـي ونئي

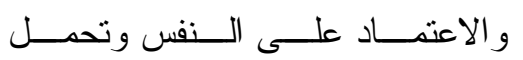
المسئولية وتحقيق الــذات و احتـــرام الحرية الفردية للطفل. 0- اتاحة فرص التفاعل مــع الآخــرين

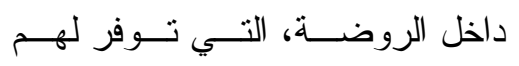

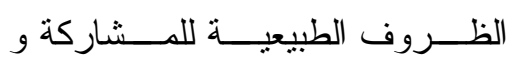
التعاون الفعال بين الزملاء وجماعـــة - الرفاق T- توطيد وتكوين علاقــات طيبـهـ مــع

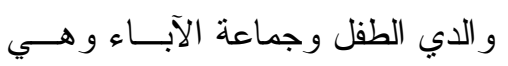
علاقة يجب أن تقوم علــى المحبـــة و التقدير و التعاون ويجب ان تتم عـن تون قناعه . - التوفيق بين الأسر المنباينة بمستوياتها النقافية و الاجتماعية و الاقتصادية.

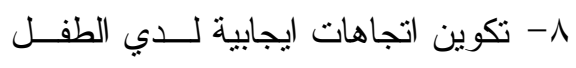
الصغير وتحوله من الفردية والأنانية واخر اجه من عزلته هذه وتحويله إلي

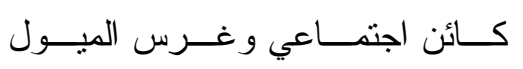

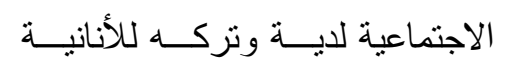
و وانصهاره في الجماعة . 9- اتاحة فرص الحركة و النشاط و اللعب بشكل حر وتتمية حب الاستطلاع لديه 


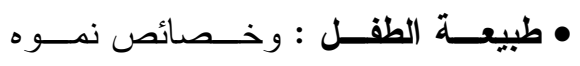

و القدرات " الملكات " التى منحها الله له.

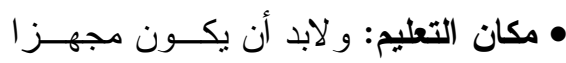

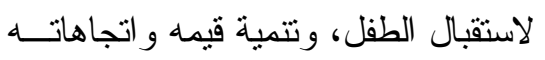
و استعداداته نحو التعلم.

• المعلمة : حيث أكدت " منتسوري " على

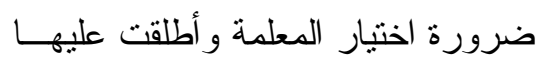

اســم " المرشـــة. (المرســى، 0 . . ب:

إن نقطة البداية الحقيقية فى تعلم طفل

ما قبل المدرسة هي ما يمكن أن بقــوم بـــهـ

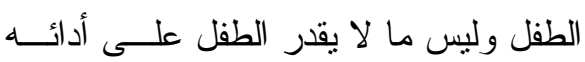

و هذا الأمر يعتمد بشكل كبير على ملاحظـــة

الطفل ملاحظة مباشرة ، و هذا ما قامت به "

منتسوري " عندما عهد إليها بتربية وتهذيب

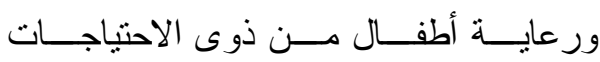

الخاصة، فالمالاحظة هي العامل الأساسي فى الإنى

التعرف على ما يستطيع الطفـلـل أن يؤديـــهـ التهيه

ويقوم به فهذا أفضل ما يمكن أن يتحقق فـى مي لـ

كل مرحلة من مر احل نموه ونتيجة وجــود

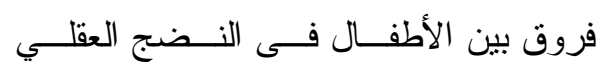

و الاجتماعي حيث لا يتم بطريقة منتظمة لدى

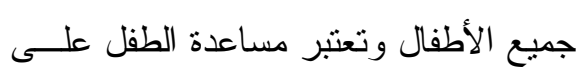

النمو فى الاتجاه الصحيح أحد هــدفين مــن الصن

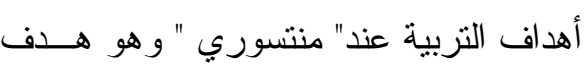

بيولوجي تسعى من خلاله إلى مر اعاة نمــو هون
الذي طالب بعودة الطفل إلى أحضان الطبيعة

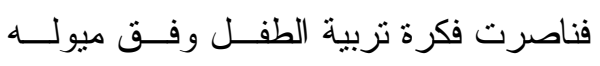
وقامت بعمل إبداعي إجرائي لتتمية الطفـلـ روحياً وفكرياً وحركياً عبر مجمو عة أنشطة تلبي حاجاته وتتمي إمكانياته داخل مؤسسات متخصصة طبقاً لمو اصفات و أهداف تعليمية معينة مله

وتـــأثرت منتــسور بـ بالاتجاهــــات و الأفكار التزبوية لبـستا لــوزي وروســو وفروبل خاصة فيما يتعلق بأهمية وضرورة الانتقال من عملية التعليم الي عملية التعلم ومن المعلم الي الطالب ، حيث تهدف التربية في بيوت الأطفال لمنتسوري الــي تكـــين شخصية الأطفال وتتمية حركاتهم وســلامة

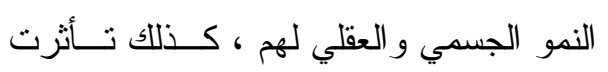
منتسوري بأفكار فروبل التربوية وريــاض الأطفال التي أنشأها ، ومما ميز منتـسوري عن بستا لــوزي وروســو أن منتـسوري ميزي مانسي

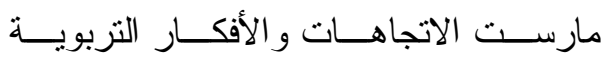
ممارسة عملية على أرض الو اقع التربــوي

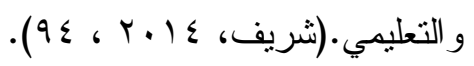
ان المتتبع و القارئ لفلسفة منتـسوري التزبوية يجد نفسه أمام ثناث أسس مهمه أو لبنات مهمه جداً في فلسفة منتسوري التربوية

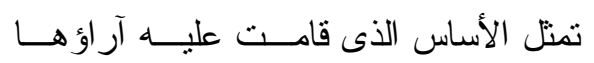
التزبوية فى تربية طفل ما قبــلـ المدرســـة 
وطاقاته الكامنة و استغلال الأنشطة و اللعــب

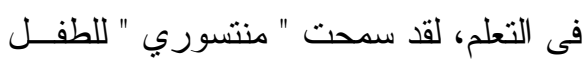

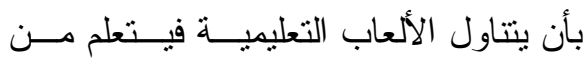

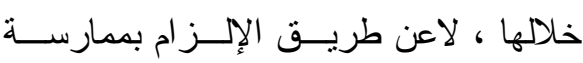

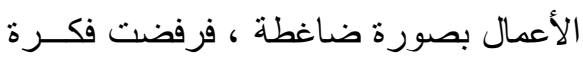

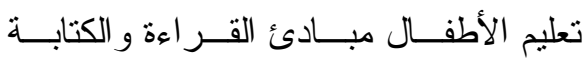
و الحساب بهذه الطريقة الشكلية التقليدية ولكن هناك طرقًا ووسائل أخرى يمكن أن يتعلم بها الأطفال ومن هنا يمكن الاستدلال على فكرة

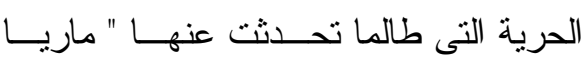
منتسوري حرية الطفل فى أن يختار الألعاب

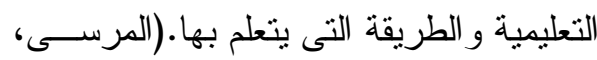
.$(V \Lambda-V V: Y . .0$

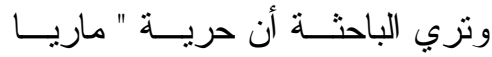

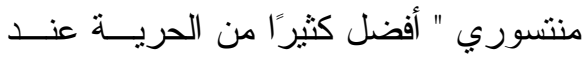

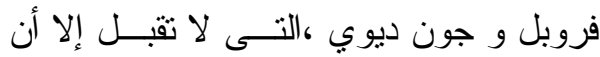

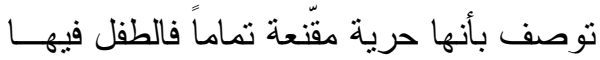

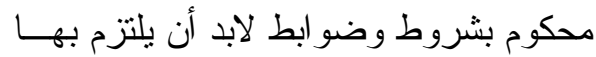

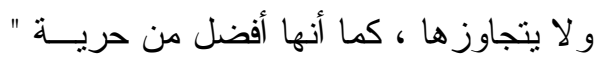

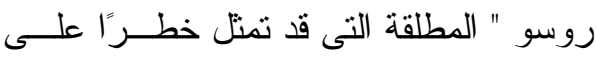
الطفل إذا ترك بمفرده يتعامل مع البيئة مــن رون

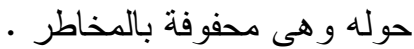
و الفكرة الأساسية " لمنتسوري " حول بل تعليم الأطفال القر اءة و الكتابة والأعداد تعتمد

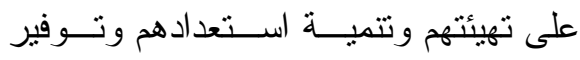
الظروف التى تتناسب مع قدر ات و إمكانــات الطفل فى هذه السن المبكرة ، وأن تعلم هذه
الطفل و الأخذ في الاعتبار مر احل نموه عند

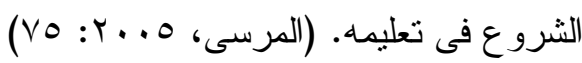

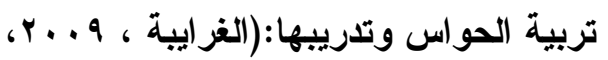
دعت " منتسوري " إلــى الاهتمــام بالتربية عن طريق اللعب من خلال تــدريب

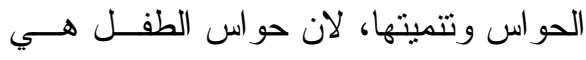

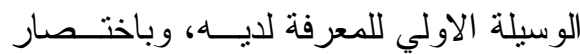
شديد يمكن القول إن منتسوري اعتمدت على لى

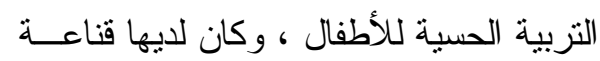
بأن الطفل الصغير يتعلم باســتخدام حو اســـة

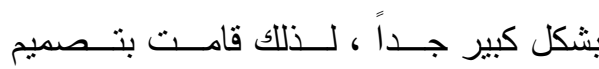
برنامجها الذي لاقي رواجاً عالمياً في تربيـــة فئة

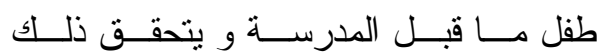
بطريقتين:- الأولى: اللعب التعليمية . - والثانية : عن طريسـق جـــب انتبــــاه الأطفال لتعرف العلاقة بــين الأســـاء

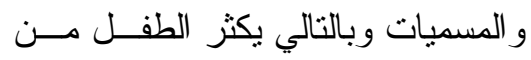
استعمال هذه الكلمات فى اكتساب اللغـــة

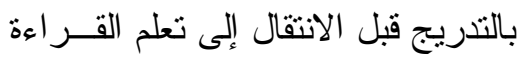

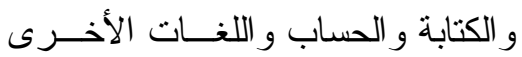

$$
\text { بشكل مدرسي . }
$$

تري منتسوري أن التعليم لا يجب أن

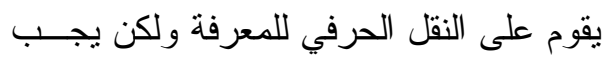
أن يأخذ مسارًا جديدًا ير اعى فيه حرية الطفل 


$$
\begin{aligned}
& \text { ب- تشجيع أسلوب الثواب للطفـل لأنـــه }
\end{aligned}
$$

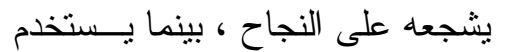

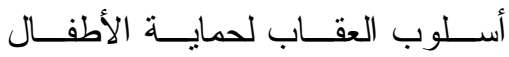

$$
\begin{aligned}
& \text { الآخرين وليس الهذف منـــه عقــاب } \\
& \text { الطفل . - الط } \\
& \text { ؟- المعلمة مرشده وموجهه للطفـلـل و لا }
\end{aligned}
$$

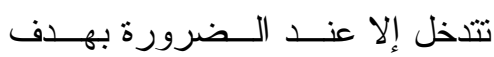

$$
\begin{aligned}
& \text { التوجيه و الإرشاد. } \\
& \text { تهذف الأدو ات التزبوية و التثقيفية التى لإنى }
\end{aligned}
$$

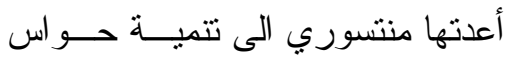

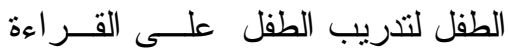

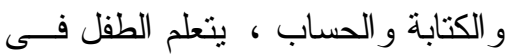

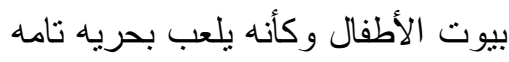

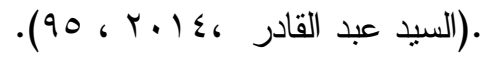

$$
\begin{aligned}
& \text { ما هي الفتــرات الحــساسة فــي فأـسفة } \\
& \text { منتسوري التربوية:- }
\end{aligned}
$$


ولتحويل معلمة رياض أطفال عادية لمعلمة

منتسوري هناك ثلاثة مر احل للتطور: -

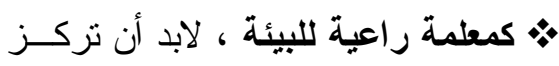

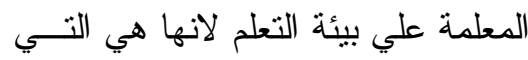

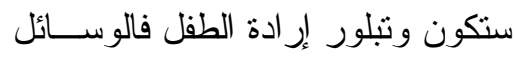

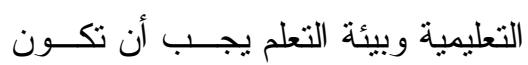

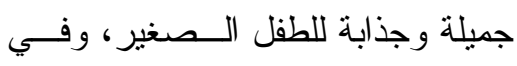

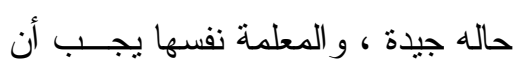

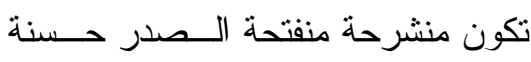

المظهر ، حتي يتمكن الطفل الصغير من

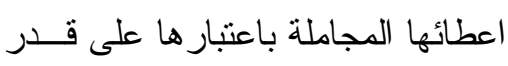

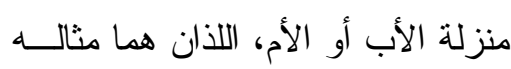

$$
\text { الطبيعي للجمال. }
$$

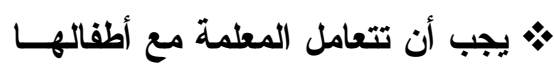

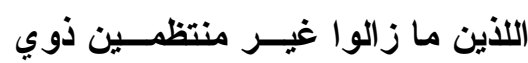

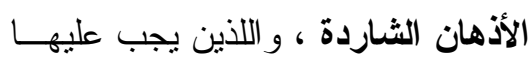
اجتذابهم اليها ليركزو ا على شيء مسنـ

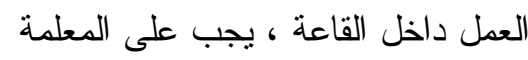
أن تكون ماهرة وتنستطيع اســتخدام أي دي لئي

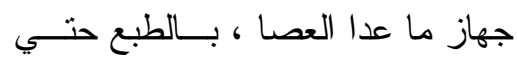
تكسب انتباه الأطفال وتقتر ح الأنـشطة فئة التعليمية بطريقة ذكية.

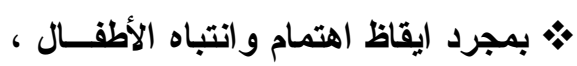
عن طريق بعض التدرييات في القاعات لأن الوسائل التعليمية لم تصبح مناسبة لئن

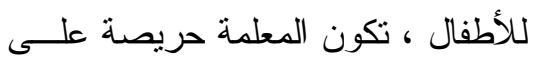

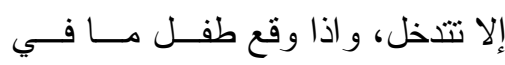

المعلمة في قاعات منتسوري، فعليها أن تبتعد

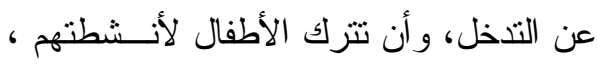

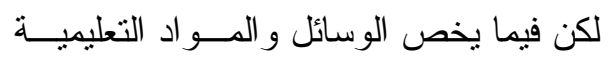

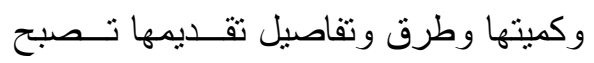

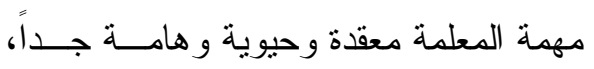

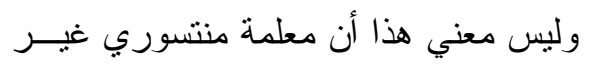

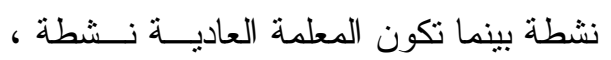

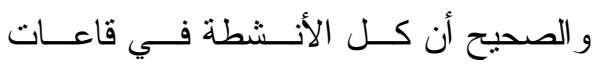
منتسوري تتطلب إعداد نشط وتوجيــه مــن

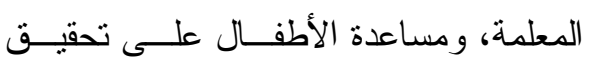

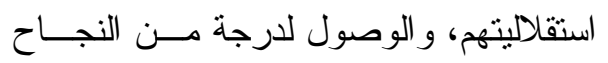

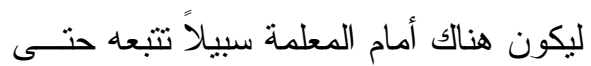
تتطور • بالنالي لا يمكن لمعلمة رياض أطفال

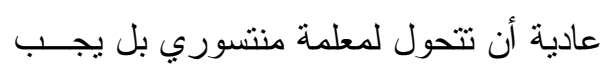

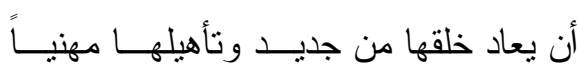

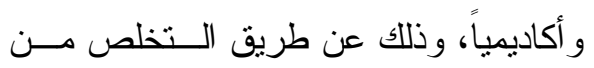

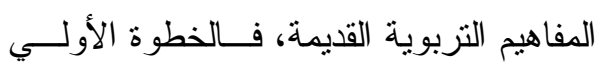

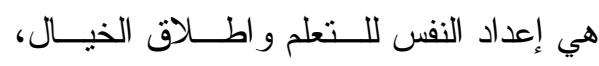

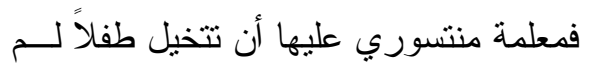
يوجد بعد، وبمعني مادي، أن يكــون لــديها

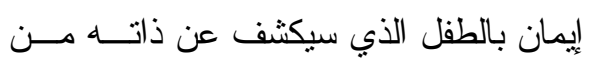

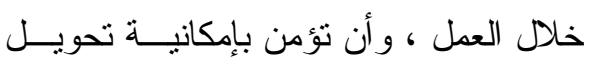

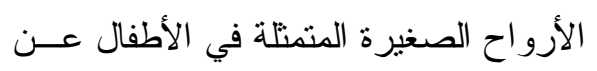
طريق الاعتتاء بهم وتهيئتهم للعمل وإثـارة

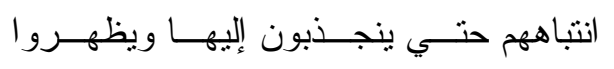

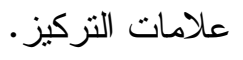


ونتيجة لمـــا ســبق فقــد دعــت "

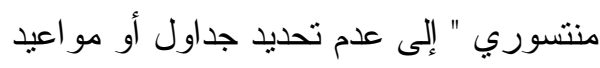

در اسية أو دروس توضع و إنما يترك للطفل

نوع التعلم الذى يفضله ويحبـــه وباســتخدام

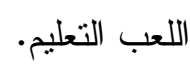

وللمصداقية كانت هناك بعض الاتتقاضــات

الموجهة لمنهج منتسوري التربوي منها:-

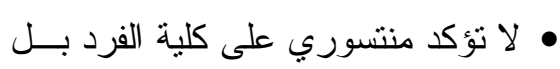

$$
\text { تربي كل حاسة بمفردها. }
$$

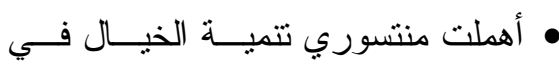

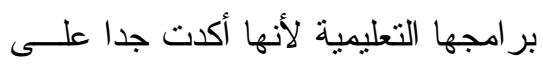

$$
\text { الحو اس. }
$$

• أهملت الحاسة الأدبية عند الطفل. • اعتمدت على تعليم الحروف ثم الكلمات العله

$$
\text { فالجمل. }
$$

• رغم تأثز ماريا منتسوري بالدين إلا أنها

لم تضع معالم و اضحة للتزبية الدينية.

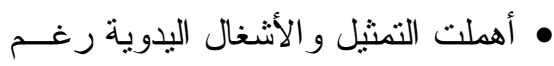

$$
\text { أهميتها و مناسبتها للأطفال. }
$$

متطلبات تطوير مؤسسات ما قبل المدرســة

في ضوء القلسفة التربوية لمنتسوري:-

$$
\text { 1- وضع آلية للتخطيط و التطــــير فــي }
$$

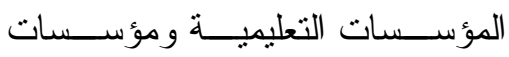

رياض الأطفال، وجعل هـــة الآليــة

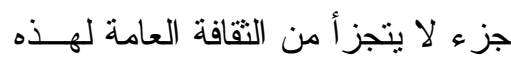

$$
\text { المؤسسات. }
$$

صعوبة لا يجب أن تريه المعلمة طريقة

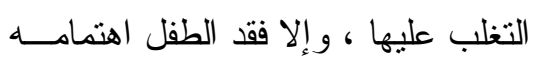

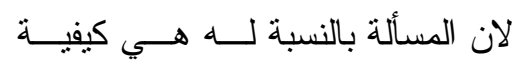

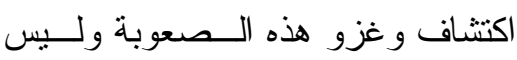

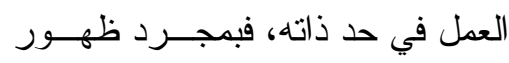

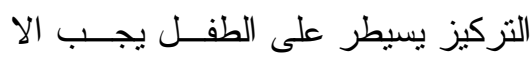

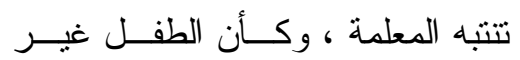

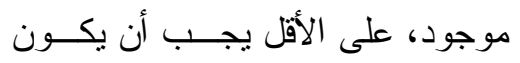
الطفل هادئًا غير واع بانتباه المعلمة له. له. وتهتم الفلسفة المنتسـورية بهــدفين أساســيين: - (مجلـــة الطقولـــة و التربيـــة (VT G Y 106

هدف بيولوجي: لمساعدة الطفل على النمو الطبيعي. هاف اجتماعي: لمساعدة الطفل على

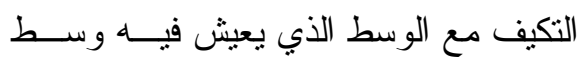
أقر انه ومجتمعه.

لهذا تعتمد الروضة عنــــــنــسوري

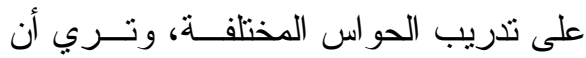
المنبهات الحسية من أهم الحوافز التي تثيــــر اهتمام الأطفال في هذه المرحلة المبكرة مــن اهن أعمار هم ، وتنتخدم منتسوري هذه المنبهات

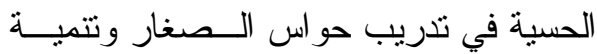
نشاطهم العقلي وذكــائهم و هـــذه الطريقـــة تتمانتي مع الاتجاهات التزبوية المعاصرة. 


$$
\begin{aligned}
& \text { • 1- الاهتمام بالتغيير و التطوير في رياض } \\
& \text { الأطفال و عدم التمسك بما هو تقليدي } \\
& \text { ونمطي. } \\
& \text { 1ا - إغناء البيئة المحيطة بالطفل بمثير ات } \\
& \text { حسية في مختلف المجــالات و التــي لئهي } \\
& \text { تهتم بالفتر ات الحساسة التــي يكــون }
\end{aligned}
$$

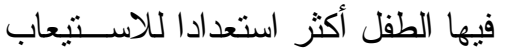

$$
\begin{aligned}
& \text { و الإدر الك. } \\
& \text { rا-جعل الطفل في الروضة هو محــور } \\
& \text { العملية التعليمية وليست المعلمة. }
\end{aligned}
$$

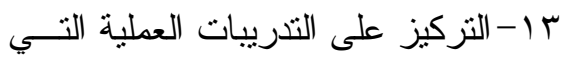

$$
\begin{aligned}
& \text { تفيد في تثبيت المعلومة لدي الطفـلـل } \\
& \text { وتقيد في النمو الحركي لديه. } \\
& \text { ع ا-ملاحظة تعلم الأطفال ومدي استيعابهر }
\end{aligned}
$$

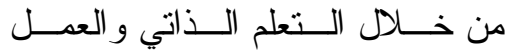

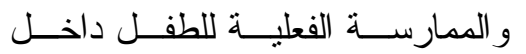

$$
\begin{aligned}
& \text { القاعات برياض الأطفال. } \\
& \text { 10-نبادل الخبر ات و المعلومسـات حــول الاطعل } \\
& \text { فلسفة منتسوري التزبوية من خــلال } \\
& \text { التدريبات وعقد الدورات المتخصصة من لتربه }
\end{aligned}
$$

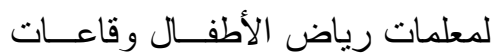

$$
\begin{aligned}
& \text { المنتسوري وكيفية التذريس فيها. } \\
& 7 \text { ا إقامة المحاضر ات و الورش التعليميــة }
\end{aligned}
$$

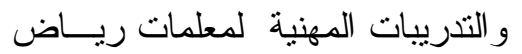

$$
\begin{aligned}
& \text { الأطفال بـشكل مـستمر لتبــصير هم }
\end{aligned}
$$

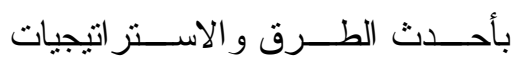

$$
\begin{aligned}
& \text { التدريسية لطريقة منتسوري فى إدارة }
\end{aligned}
$$

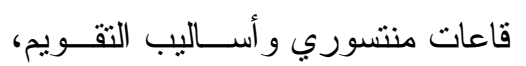

$$
\begin{aligned}
& \text { لطفل الروضة. }
\end{aligned}
$$


ا Y-الاستفادة من خبرات الدول المتقدمـــة

عن فلسفة منتسوري التربويــة فــي

الميادين التعليمية في مؤسسات رياض

الأطفال.

معوقات تطوير مؤسسات رياض الأطفال:-

1- نقص الدور ات المقدمة للتتمية المهنية

$$
\text { لمعلمات ومشرفات الروضات. }
$$

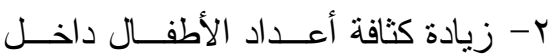

$$
\text { القاعات. }
$$

ب- ضــــف درايـــة المــسئولين عــن

مؤسسات رياض الأطفال و التوجيــــ

الفنـــي و الإدارة بالروضــــة بفلــسفة

و أهداف منتسوري التربوية في مرحلة

$$
\text { رياض الأطفال. }
$$

ع - اهتمام مديري الروضــــات بـــالنو احي

الإدارية، على حساب العملية التربوية

داخل القاعات.

0- جمود أنــشطة منتسـوري وعـدم

مرونتها بما يتتاسب مع مناهج رياض

الأطفال الحالية وتحتاج للتطوير بمـــا

$$
\text { يتتاسب مع المناهج الحالية. }
$$

7- قلة تو افق مناهج الأنشطة المقدمة في

رياض الأطفال مع المتطلبات الحديثة

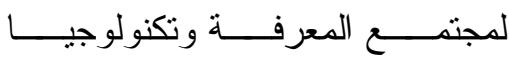

$$
\text { المعلومات. }
$$

-V نقص إمكانيــات الروضــــة الماديـــة

اللازمة لتنفيذ البــر امج المخصــصة
و التعامل مع الأطفال بأحدث الطــرق

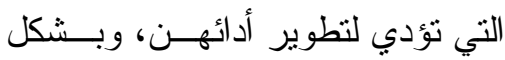

مستمر لمو اكبة التطور ات في مجـــال التعليم و التعلم و الإعداد لله.

IV

رياض الأطفال وتطوير ها في ضـــو

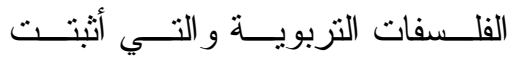

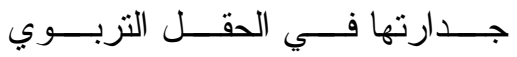

$$
\text { و التعليمي. }
$$

1 ا -حل المشكلات التي تواجه المعلمــات

و اطلاعهن على أحــدث النظريــات

التربوية و النفسية و الطـــرق الفعالـــة

وتقنيات التعليم الحديثـــة، وتــدريبهن

على اســتخدام وســـائل التكنولوجيــا

و التدريس الحديثة لتكون قادرة علــى

تطوير نفسها لمو اكبة تغير ات العصر •

9 1 - ضرورة أن تتضمن مقررات كليــات

التربية وكليات رياض الأطفال علـي

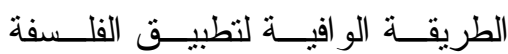

التزبوية لمنتسوري فـي مؤسـسـات الفوله

رياض الأطفــال لإعــــاد معلمـــات

رياض الأطفال في ضوء مـستجدات

- العصر

• - إقامة بر امج تدريبية لمعلمات رياض

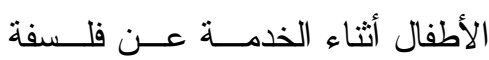

منتسوري التربوية، وكيفية تطبيقهــا في مؤسسات رياض الاطفال. 


$$
\begin{aligned}
& \text { طنطا، المجلد( ع ب)العدد(الر ابع) الجــزء } \\
& \text { r- المهدى، مجدى صلاح طه (ع ( + ) ): } \\
& \text { فلسفة تربيــة الطفــل بــين الأصــالة }
\end{aligned}
$$

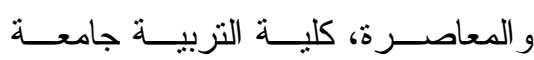

$$
\begin{aligned}
& \text { المنصورة ،اليمامة للنشر و التوزيع • }
\end{aligned}
$$

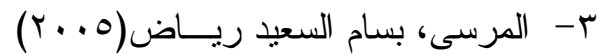

$$
\begin{aligned}
& \text { ظاهرة التعليم المدرسي فــي ريــاض } \\
& \text { الأطفال بين الفكر و التطبيــق، رســـالة } \\
& \text { ماجستير ، قسم أصول التزبيــة، كليــة } \\
& \text { التربية، جامعة المنصورة. }
\end{aligned}
$$

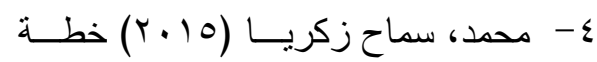

$$
\begin{aligned}
& \text { إستر اتيجية مقترحة لنطوير مؤسـسات }
\end{aligned}
$$

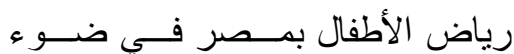

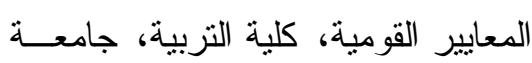

$$
\begin{aligned}
& \text { المنوفية . المناية } \\
& \text { 0- متولي، محمد خليفة اسماعيل(0 (10): } \\
& \text { مدخل منتسوري و أثزه فــي إكــساب } \\
& \text { بعض مهار ات الحياة العملية لاى طفل } \\
& \text { الروضة من وجهة نظر الأمهات، مجلة }
\end{aligned}
$$

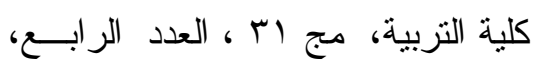

$$
\begin{aligned}
& \text { كلية التزبية، جامعة أسيوط. } \\
& \text { צ- الغر ايبة، سالم على(9 . . . ) )، مهار ات }
\end{aligned}
$$

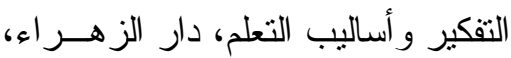

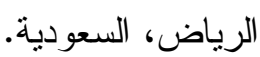

$$
\begin{aligned}
& \text { منتسوري التزبوية. }
\end{aligned}
$$

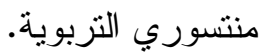

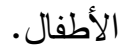




$$
\begin{aligned}
& \text { r ا-الثيباني، حلمى على محمد (1 ( . ( ) : } \\
& \text { - V } \\
& \text { مشكلات رياض الأطفال فى الجمهورية } \\
& \text { اليمنية من وجهة نظر العربية. } \\
& \text { r ا-شريف، السيد عبد القـادر، (ع ( ب ) ): } \\
& \text { المدخل إلــى ريــاض الأطفــال، دار } \\
& \text { الجو هرة للنشر و التوزيع، القاهرة. }
\end{aligned}
$$

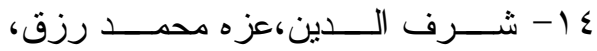

$$
\begin{aligned}
& \text { (T) } \\
& \text { الأطفال فى ضو ءء الفلــسفات التزبويـــة } \\
& \text { المعاصرة لطفل ما قبل المدرسة دراسة فئة } \\
& \text { تحليلية نقديه ، رسالة دكتور اه الفلـسفة }
\end{aligned}
$$

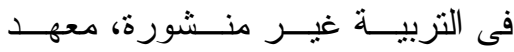

$$
\begin{aligned}
& \text { الدر اسات التربوية ،جامعة القاهرة. }
\end{aligned}
$$

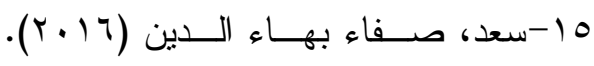

$$
\begin{aligned}
& \text { مؤسسات رياض الأطفال فـي مــصر }
\end{aligned}
$$

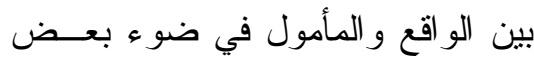

$$
\begin{aligned}
& \text { الخبرات الحديثــة: در اســـة تقويميــة، }
\end{aligned}
$$

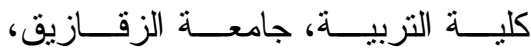

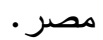

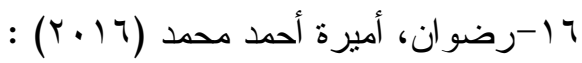

$$
\begin{aligned}
& \text { إدارة مؤســـــات ريـــــاض الأطفــــال } \\
& \text { الحاصــلة علـى الاعتمــاد، (در اســـة } \\
& \text { تقويميــة)، رســـالة ماجـستير غيــر }
\end{aligned}
$$

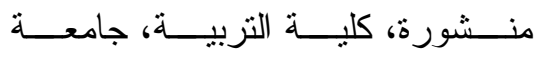

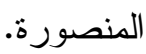

$$
\begin{aligned}
& \text { مقتر ح لنطوير إدارة مؤسسات ريــاض }
\end{aligned}
$$

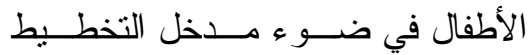

$$
\begin{aligned}
& \text { الاستر اتيجي، - كلية رياض الأطفــال } \\
& \text { - قسم العلوم التزبوية ، جامعة الفيوم. }
\end{aligned}
$$

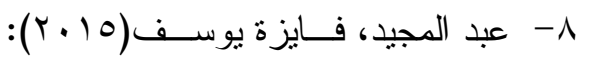

$$
\begin{aligned}
& \text { در اسة مقارنة بين مـــهج منتسـسوري } \\
& \text { و المنهج المطور التابع لوزارة التربيــة } \\
& \text { و التعليم المصرية فى فــدر ات التفكيــر } \\
& \text { الابتكاري، -معهد الدر اســات العليــا } \\
& \text { للطفولة، جامعة عين شمس. } \\
& 9 \text { - طلبه، جابر محمود، (999 (1)):التجديــ } \\
& \text { التربوي من أجل جامعة المستقبل، من } \\
& \text { آفاق الخطاب التزبــوي (r)، الإيمــان }
\end{aligned}
$$

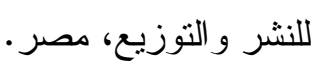




\begin{tabular}{|c|c|}
\hline Altemative Way of Teaching & 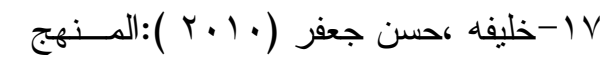 \\
\hline Science. Master of Science in & المدرسى المعاصر ، مكتبـــة الر اثـــد، \\
\hline Education, Science Education, & 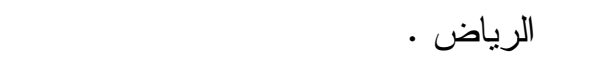 \\
\hline Lehman College. & 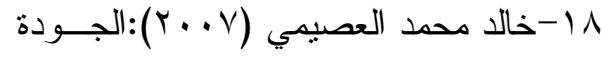 \\
\hline 2- Amy , Amy E.Allen (2008). & فى التعليم العام ،مركز المـلــــ خالـــــــ \\
\hline الاستر اتيجيات التعليمية فى تعليم المدرســين & 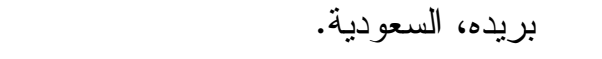 \\
\hline فى مرحلة الطفولة المبكرة V-(مقارنة بــين & المراجع الأجنبية: المراجية \\
\hline نهجين). & $\begin{array}{l}\text { 1- Mwape, James. (2004). The } \\
\text { Montessori Curriculum: An }\end{array}$ \\
\hline
\end{tabular}

